\title{
Early trends and predictors of renal function following computed tomography-guided percutaneous cryoablation of a renal mass in patients with and without prior renal impairment
}

Tendências iniciais e preditores de função renal após crioablação percutânea guiada por tomografia computadorizada de massa renal em pacientes com e sem comprometimento renal prévio

\section{Pedro V. Staziaki ${ }^{1,2, a}$, Harshna V. Vadvala ${ }^{1,3, b}$, Vanessa Fiorini Furtado ${ }^{1,2, c}$, Dania Daye ${ }^{1, d}$, Ronald S. Arellano ${ }^{1, e}$, Raul N. Uppot ${ }^{1, f}$}

1. Massachusetts General Hospital, Harvard Medical School, Boston, MA, USA. 2. Boston Medical Center, Boston University School of Medicine, Boston, MA, USA. 3. Johns Hopkins Hospital, Johns Hopkins University, Baltimore, MD, USA.

Correspondence: Harshna V. Vadvala, MD. Body Imaging Division, Radiology Department, Johns Hopkins Hospital, Johns Hopkins University. 601 North Caroline Street, Baltimore, MD 21287, USA. Email: drharshna@gmail.com; hvadval1@jhmi.edu.

a. https://orcid.org/0000-0003-3219-3815; b. https://orcid.org/0000-0002-2067-8201; c. https://orcid.org/0000-0001-9384-9668; d. https://orcid.org/0000-0002-2230-7199; e. https://orcid.org/0000-0001-9232-4069; f. https://orcid.org/0000-0001-6165-4911. Received 26 July 2019. Accepted after revision 12 September 2019.

How to cite this article:

Staziaki PV, Vadvala HV, Furtado VF, Daye D, Arellano RS, Uppot RN. Early trends and predictors of renal function following computed tomographyguided percutaneous cryoablation of a renal mass in patients with and without prior renal impairment. Radiol Bras. 2020 Mai/Jun;53(3):141-147.

Abstract Objective: To assess trends and predictors of the glomerular filtration rate (GFR) after renal mass cryoablation in patients with and without history of renal impairment.

Materials and Methods: This was a retrospective study of 39 patients who underwent computed tomography-guided percutaneous cryoablation of a renal mass, divided into two groups: those with prior renal impairment (PRI+); and those without prior renal impairment (PRI-). The GFR trend and the chronic kidney disease stage were evaluated at baseline, as well as at 1, 6, and 12 months after cryoablation. Predictors of GFR at 1 and 6 months were modeled with linear regression.

Results: In both groups, the mean GFR at 1 month and 6 months was significantly lower than at baseline $(p<0.001$ and $p=0.01$, respectively). Although the GFR was lower across all time points in the PRI+ group $(-26.1 ; p<0.001)$, the overall trend was not statistically different from that observed in the PRI- group $(p=0.89)$. Univariate analysis showed that the decline in GFR at 1 and 6 months correlated with the baseline GFR $(0.77$ and $0.63 ; p<0.001$ and $p=0.03$, respectively) and with the size of the ablation zone ( -7.6 and -12.84 , respectively; $p=0.03$ for both). However, in the multivariate model, baseline GFR was predictive only of GFR at 1 month $(p<0.001)$.

Conclusion: The trend in GFR decline after cryoablation is similar for patients with and without a history of renal impairment. Baseline GFR predicts the mean GFR in the early post-cryoablation period.

Keywords: Radiology, interventional; Renal insufficiency; Kidney/physiopathology; Glomerular filtration rate; Tomography, X-ray computed/methods.

Resum o Objetivo: Medir as tendências iniciais da função renal pela taxa de filtração glomerular (TFG) em pacientes com e sem comprometimento renal prévio após crioablação renal.

Materiais e Métodos: Este é um estudo retrospectivo de 39 pacientes submetidos a crioablação percutânea guiada por tomografia computadorizada de massa renal. Os pacientes foram divididos em dois grupos: com comprometimento renal prévio (CRP+) e sem comprometimento renal prévio (CRP-). As tendências da TFG foram avaliadas nos tempos 0, 1, 6 e 12 meses com o estadiamento de doença renal crônica. Preditores da TFG em 1 e 6 meses foram modelados usando regressão linear.

Resultados: Em ambos os grupos houve declínio da TFG média após 1 e 6 meses $(p<0,001$ e $p=0,01$, respectivamente). Apesar de o grupo CRP+ demonstrar média menor da TFG em cada um dos tempos ( $-26,1 ; p<0,001)$, a tendência de forma geral não foi estatisticamente diferente do grupo $\operatorname{CRP}-(p=0,89)$. Análise univariada mostrou correlação da TFG no tempo $0(0,77$ e 0,$63 ; p$ $<0,001$ e $p=0,03$, respectivamente) e tamanho da ablação $(-7,6$ e -12,84; $p=0,03)$, com declínio em 1 e 6 meses. Porém, no modelo multivariado, apenas a TFG no tempo 0 foi preditiva da TFG em 1 mês $(p<0,001)$.

Conclusão: A curva de tendência de declínio da TFG após crioablação foi similar entre os pacientes dos grupos CRP+ e CRP-, sem mudanças no estadiamento de função renal. A TFG no tempo 0 foi preditiva da TFG média no período de crioablação inicial.

Unitermos: Radiologia intervencionista; Insuficiência renal; Rim/fisiopatologia; Taxa de filtração glomerular; Tomografia computadorizada/métodos. 


\section{INTRODUCTION}

The advent of cross-sectional imaging has made it possible to identify smaller renal masses ${ }^{(1,2)}$. Although nephrectomy has historically been the established standard of treatment for such masses, it has been shown to increase the risk of chronic kidney disease (CKD) and might therefore no longer be considered the gold-standard treatment for small renal tumors ${ }^{(3)}$. Even partial nephrectomy has been shown to increase the risk of a decline in renal function by up to $20 \%{ }^{(4)}$. Therefore, minimally invasive technologies, also known as nephron-sparing approaches, are rapidly gaining acceptance.

Percutaneous cryoablation is considered for patients who present with small, incidentally detected renal tumors (ideally $<4 \mathrm{~cm}$ in diameter and limited to the kidney), as well as for those who are poor surgical candidates (because of advanced age or significant comorbidity) and those who need nephron-sparing treatment options as a way to postpone or avoid the need for chronic dialysis. The last category often includes patients with CKD, a single kidney, or a genetic predisposition to multiple tumors. In addition, it is vital to monitor renal function in the early post-procedure period, especially in cancer patients with comorbidities, because further exposure to nephrotoxic agents can complicate their recovery.

Cryoablation has many advantages over traditional surgery, such as having a lower incidence of serious complications ${ }^{(5,6)}$ and producing less morbidity in the immediate post-procedure period ${ }^{(7)}$, as well as being more afford$a_{b l e}{ }^{(8)}$. Initial studies of cryoablation demonstrated favorable outcomes ${ }^{(9-11)}$ and proved it to be a safe, effective treatment ${ }^{(12-17)}$. Nevertheless, renal function is one of the most important considerations in devising treatment strategies for the management of renal masses and it remains unclear to what extent cryoablation affects renal function, particularly among patients with a history of renal impairment.

The objective of this study was to determine trends in renal function after cryoablation of a renal mass in patients with and without a history of renal impairment, comparing the two groups. A secondary objective was to identify predictors of post-cryoablation renal function.

\section{MATERIALS AND METHODS}

\section{Study design}

This was a single-center retrospective study. This investigation was approved by the local institutional review board, which waived the need for informed consent. We included all consecutive patients who underwent computed tomography (CT)-guided percutaneous cryoablation of a renal mass at a tertiary-care teaching hospital between April 2009 and August 2012. Patients who did not undergo follow-up renal function testing were excluded, as were those subsequently requiring additional cryoablation treatment.
The eligible patients were divided into two groups: those with prior renal impairment (PRI+) and those without (PRI-). Patients were included in the PRI+ group if they had a glomerular filtration rate (GFR) $<60 \mathrm{~mL} /$ $\min / 1.73 \mathrm{~m}^{2}$, a reported diagnosis of $\mathrm{CKD}$, a congenital single kidney, or a history of radical or partial nephrectomy, as well as if they had previously undergone renal thermal ablation. The patients in the PRI- group had no history of renal impairment or renal intervention (i.e., had healthy kidneys).

The renal function marker of interest was the GFR, which was determined at four time points: baseline (the last measurement before ablation); and 1, 6, and 12 months after ablation. The primary endpoint was a postcryoablation trend toward a decline in renal function. The secondary endpoints were declines in GFR at 1 month and 6 months after cryoablation.

\section{Variables of interest}

Baseline and post-ablation renal function was assessed on the basis of the GFR, calculated with the Modification of Diet in Renal Disease formula ${ }^{(18)}$, which is based on serum creatinine levels, and was recorded as a continuous variable. Covariates with a known influence on renal function were recorded at admission for the cryoablation procedure. In brief, covariates included age, sex, race, hypertension, diabetes mellitus, dyslipidemia, body mass index (BMI), smoking history, and alcohol abuse.

\section{Statistical analysis}

Baseline characteristics are presented as frequency (percentage) for categorical data and as mean \pm standard deviation or median (interquartile range) for continuous data. Continuous data were compared by using unpaired Student's t-tests or Wilcoxon rank-sum tests, as appropriate. Categorical data were compared by using the chisquare or Fisher's exact test.

The trend in renal function was evaluated in a longitudinal analysis of measurements obtained at four time points. The mean response was modeled using analysis of response profiles and tested for parallelism between the two groups. If both trends were parallel, the means were tested for time effect and group effect.

Multivariate regression was used in order to identify independent predictors of renal function at 1 month and 6 months after cryoablation. In the univariate analysis, we assessed the association of known predictors of renal impairment, which included advanced age, male sex, African American race, diabetes, hypertension, dyslipidemia, high BMI, and smoking, as well as variables related to renal disease, such as baseline GFR, a history of radical nephrectomy, a history of partial nephrectomy, prior ablation, and the size of the tumor. In the multivariate analysis, we included variables with a $p<0.10$ in the univariate analysis. 
All statistical analyses were performed with the $\mathrm{R}$ software, version 3.2.2 (The R Foundation for Statistical Computing, Vienna, Austria). A two-sided $p$-value $<0.05$ was considered statistically significant.

\section{RESULTS}

\section{Patient characteristics}

During the study period, 51 patients underwent CTguided percutaneous cryoablation of a renal mass at our institution. Twelve patients were excluded because of a lack of follow-up renal function testing or because they subsequently required additional cryoablation. Therefore, the final sample comprised 39 patients, of whom 19 (49\%) were in the PRI- group and $20(51 \%)$ were in the PRI+ group. The characteristics of the patients are presented in Table 1.

\section{Tumor characteristics and ablation results}

Details pertaining to the tumor characteristics and ablation results are presented in Table 2. Because some patients had more than one renal mass, there were 44 renal masses in total. Of those, 20 were in PRI- group patients and 24 were in PRI+ group patients. The mean tumor size was $3.1 \pm 1.2 \mathrm{~cm}$ in the PRI- group and $2.8 \pm 1.2 \mathrm{~cm}$ in the PRI+ group, the overall mean size being $3.0 \pm 1.2 \mathrm{~cm}$.

In all cases, CT-guided percutaneous cryoablation of renal tumors was performed with a mean of three cryoprobes (range, 1-6), with a length of $15-17 \mathrm{~cm}$ and a width of $2.4 \mathrm{~mm}$, and the freeze-thaw-freeze time was typically 10-8-10 min (Figure 1). There was no overall difference in the laterality of the lesions targeted for ablation, which were in the right kidney in 18 patients $(46 \%)$, in the left kidney in $20(51 \%)$, and in both kidneys in one $(2.5 \%)$. Of the 39 ablated tumors, 37 (95\%) were renal cell carcinomas, one of which is shown in Figure 1. The two remaining tumors were metastases. In one PRI+ group patient, three renal lesions were ablated concurrently.

\section{Renal function trends}

The temporal trend in GFR (as a proxy for renal function) is plotted in Figure 2. The GFR values over the 12 months evaluated are shown in Table 3. Table 4 shows the mean and percent decline in GFR.

Regarding the overall trend in our cohort, there was decline in the mean GFR at 1 month and 6 months after cryoablation, respectively, of $-9.1 \%$ (95\% confidence interval $[95 \% \mathrm{CI}]:-15.9$ to $-2.1 ; p=0.01)$ and $-15.4 \%(95 \%$ CI: -28.1 to $-2.6 ; p=0.02$ ). At 12 months after cryoablation, there was a slight recovery of renal function in the PRI- group (to $-5.4 \%$; 95\% CI: -14.8 to 3.9 ), although the difference was not statistically significant $(p=0.25)$. In the analysis of the response profiles, the mean GFR was found to be lower, at all time points, in the PRI+ group (group estimate of -26.1 ; $95 \%$ CI: -39.3 to $-12.8 ; p<0.001$ ), although testing for parallelism revealed that the trend curve was not statistically different $(p=0.89)$.

Table 1-Patient characteristics.

\begin{tabular}{|c|c|c|c|c|}
\hline \multirow[b]{2}{*}{ Variable } & \multirow[b]{2}{*}{ All patients $(n=39)$} & \multicolumn{2}{|c|}{ Prior renal impairment } & \multirow[b]{2}{*}{$P$-value } \\
\hline & & No $(n=19)$ & Yes $(n=20)$ & \\
\hline Age, mean \pm SD & $68 \pm 11$ & $66 \pm 12$ & $69 \pm 11$ & 0.36 \\
\hline \multicolumn{5}{|l|}{ Race, n (\%) } \\
\hline White & $34(87.0)$ & $16(84.0)$ & $18(90.0)$ & 0.66 \\
\hline African American & $4(10.0)$ & $2(11.0)$ & $2(10.0)$ & 1.00 \\
\hline Asian & $1(2.6)$ & $1(0.5)$ & 0 & 0.48 \\
\hline Male sex, n (\%) & 30 (76.9) & $14(73.7)$ & $16(80.0)$ & 0.70 \\
\hline $\mathrm{BMI}\left(\mathrm{kg} / \mathrm{m}^{2}\right)$, mean $\pm \mathrm{SD}$ & $33 \pm 7.9$ & $33 \pm 8.9$ & $33 \pm 6.9$ & 0.98 \\
\hline Hypertension, n (\%) & $33(84.6)$ & $14(73.7)$ & $19(95.0)$ & 0.09 \\
\hline Diabetes, n (\%) & $14(35.9)$ & $8(42.0)$ & $6(30.0)$ & 0.50 \\
\hline Dyslipidemia, n (\%) & $22(56.4)$ & $8(42.0)$ & $14(70.0)$ & 0.08 \\
\hline Smoking, n (\%) & $24(61.4)$ & $12(63.0)$ & $12(60.0)$ & 0.59 \\
\hline Alcohol abuse, n (\%) & $13(34.2)$ & $6(31.0)$ & $7(35.0)$ & 1.00 \\
\hline Follow-up (days), median (IQR) & $70(23-203)$ & $89(20-250)$ & $63(30-165)$ & 0.61 \\
\hline Baseline creatinine, mean \pm SD & $1.1 \pm 0.4$ & $0.9 \pm 0.8$ & $1.3 \pm 0.4$ & $<0.001$ \\
\hline Baseline GFR $\left(\mathrm{mL} / \mathrm{min} / 1.73 \mathrm{~m}^{2}\right)$, mean $\pm \mathrm{SD}$ & $71 \pm 25$ & $85.5 \pm 19$ & $59.4 \pm 23$ & $<0.001$ \\
\hline \multicolumn{5}{|l|}{ Type of prior renal impairment, n (\%) } \\
\hline CKD & $11(44.0)$ & 0 & $11(55.0)$ & $<0.001$ \\
\hline Single kidney & $3(7.7)$ & 0 & $3(15.0)$ & 0.21 \\
\hline Radical nephrectomy & $2(5.1)$ & 0 & $2(10.0)$ & 0.49 \\
\hline Partial nephrectomy & $5(12.8)$ & 0 & $5(25.0)$ & $<0.05$ \\
\hline Prior renal ablation & 7 (17.9) & 0 & $7(35.0)$ & $<0.01$ \\
\hline Repeated renal ablation & $1(2.6)$ & 0 & $1(5.0)$ & 0.02 \\
\hline
\end{tabular}

SD, standard deviation; IQR, interquartile range. 
Table 2-Characteristics of renal tumors submitted to cryoablation.

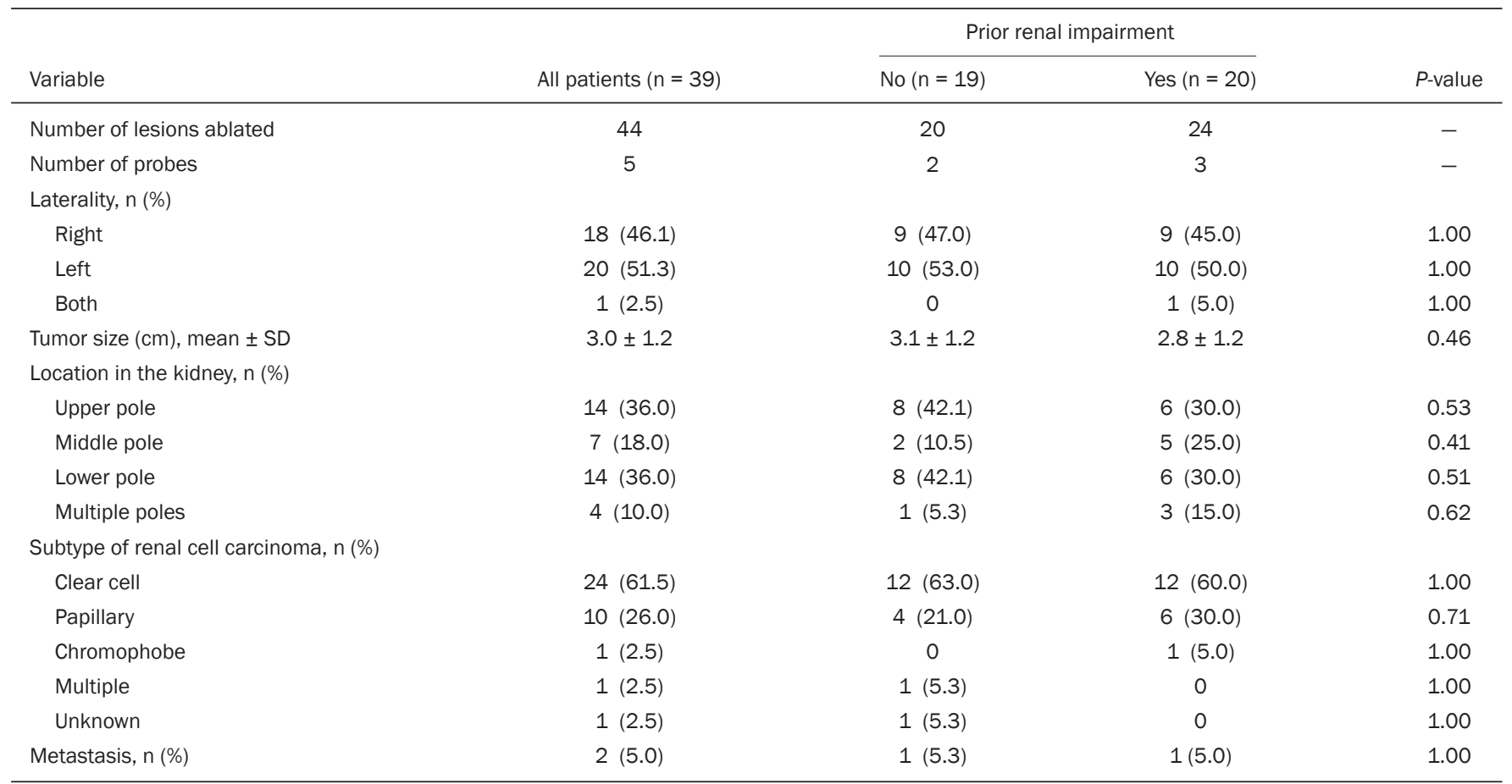

SD, standard deviation.
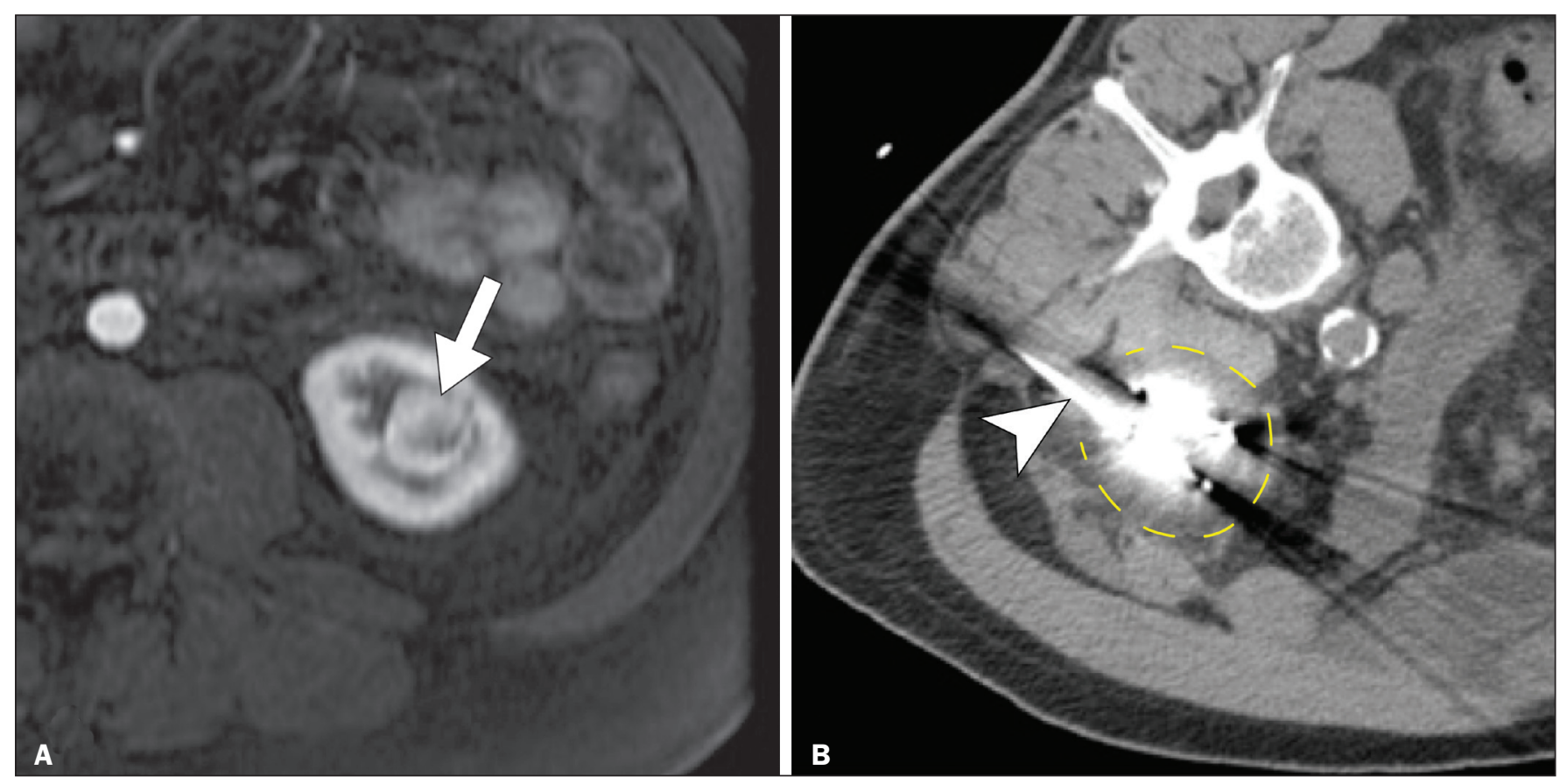

Figure 1. A 69-year-old male with a clear cell renal cell carcinoma measuring $2.5 \mathrm{~cm}$. A: Pre-procedure magnetic resonance imaging scan, in the arterial phase, showing an arterially enhancing lesion (arrow) in the middle pole of the left kidney. B: CT-guided cryoablation of the same patient in the oblique left lateral decubitus position. One of the three cryoablation probes can be seen in the image (arrowhead), as can an ice ball forming around the probe tip (dashed yellow line).

\section{Predictors of renal function}

Table 5 shows the results of the univariate and multivariate analyses performed for the 1 month after cryoablation time point. In the univariate analysis, a decline in GFR at 1 month correlated positively with the baseline GFR $(0.77 ; 95 \%$ CI: 0.59 to $0.95 ; p<0.001)$ and negatively with the size of the ablation zone $(-7.6 ; 95 \%$ CI: -14.5 to $-0.7 ; p=0.03)$. In the multivariate analysis, baseline GFR retained its effect $(0.78$; $95 \%$ CI: 0.6 to 1.0 ; $p<0.001)$, although the size of the ablation zone was no longer a significant predictor $(0.34 ; 95 \% \mathrm{CI}:-4.1$ to 4.8 ; $p=0.88)$. 


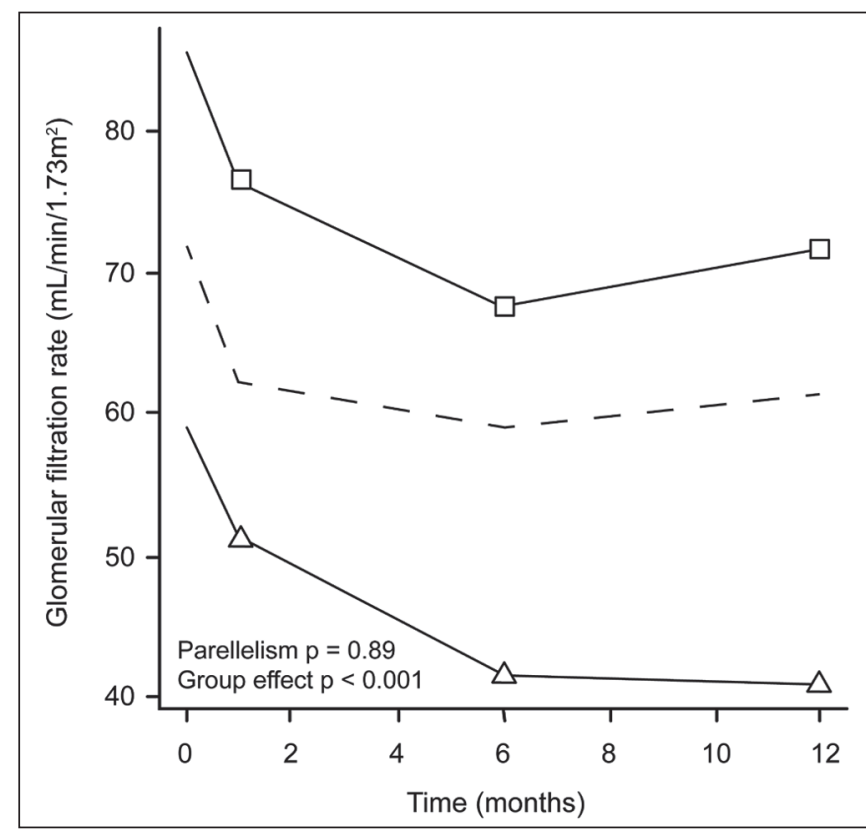

Figure 2. Mean GFR trend over 12 months in the PRI- group (squares), the $\mathrm{PRI}+$ group (triangles), and the sample as a whole (dashed line). Despite the post-cryoablation decline in renal function, the GFR never dropped below 30 $\mathrm{mL} / \mathrm{min} / 1.73 \mathrm{~m}^{2}$ in either group.

Table 3-GFR trends at multiple time points.

\begin{tabular}{lcccc}
\hline & & \multicolumn{2}{c}{ Prior renal impairment } & \\
\cline { 3 - 4 } Time point & $\begin{array}{c}\text { All patients } \\
(\mathrm{n}=39)\end{array}$ & $\begin{array}{c}\text { No } \\
(\mathrm{n}=19)\end{array}$ & $\begin{array}{c}\text { Yes } \\
(\mathrm{n}=20)\end{array}$ & P-value \\
\hline Baseline & $71 \pm 25$ & $85.5 \pm 19$ & $59.4 \pm 23$ & $<0.001$ \\
1 month & $62 \pm 22$ & $76.4 \pm 19$ & $51.3 \pm 19$ & 0.001 \\
6 months & $60 \pm 20$ & $67.6 \pm 22$ & $41.5 \pm 5$ & 0.01 \\
12 months & $61 \pm 31$ & $71.7 \pm 33$ & $40.7 \pm 5$ & 0.07 \\
\hline
\end{tabular}

Table 6 shows the results of the univariate and multivariate analyses performed for the 6 months after cryoablation time point. In the univariate analysis, a decline in GFR at 6 months correlated positively with the baseline GFR $(0.63 ; 95 \%$ CI: 0.1 to $1.2 ; p=0.03)$ and negatively with the size of the ablation zone $(-12.84 ; 95 \%$ CI: -23.8 to $-1.9 ; p=0.03$ ). However, in the multivariate analysis, no significant effect was observed for the baseline GFR $(0.41 ; 95 \%$ CI: -0.2 to $1.02 ; p=0.16)$ or for the size of the ablation zone $(-8.6 ; 95 \% \mathrm{CI}:-20.8$ to $3.6 ; p=0.15)$.

\section{DISCUSSION}

In our study, we evaluated the trends in renal function (GFR) after cryoablation of renal masses, comparing patients with and without a history of renal impairment. Although renal function decreased after cryoablation, the renal disease staging, according to the latest (2012) National Kidney Foundation Kidney Disease Outcomes Quality Initiative guidelines ${ }^{(19)}$, remained unchanged in both groups. At 12 months after cryoablation, the patients in the PRI- group remained in the same GFR category
Table 4-Mean and percent GFR decline over 1 year.

\begin{tabular}{lccc}
\hline & & \multicolumn{2}{c}{ Prior renal impairment } \\
\cline { 3 - 4 } Time point & $\begin{array}{c}\text { All patients } \\
(\mathrm{n}=39)\end{array}$ & $\begin{array}{c}\text { No } \\
(\mathrm{n}=19)\end{array}$ & $\begin{array}{c}\text { Yes } \\
(\mathrm{n}=20)\end{array}$ \\
\hline 1 month & $9(-12.7)$ & $9.1(-10.6)$ & $8.1(-13.6)$ \\
6 months & $11(-15.5)$ & $17.9(-20.9)$ & $17.9(-30.1)$ \\
12 months & $10(-14)$ & $13.8(-16.1)$ & $18.7(-31.5)$ \\
\hline
\end{tabular}

Table 5-Linear regression for the 1 month after cryoablation time point.

\begin{tabular}{|c|c|c|c|c|}
\hline \multirow[b]{2}{*}{ Variable } & \multicolumn{2}{|c|}{ Univariate analysis } & \multicolumn{2}{|c|}{ Multivariate analysis } \\
\hline & Estimate & $P$-value & Estimate & $P$-value \\
\hline Age & $-0.5(-1.2$ to 0.2$)$ & 0.13 & - & - \\
\hline Male sex & $-15.5(-34$ to 3.0$)$ & 0.10 & - & - \\
\hline $\begin{array}{l}\text { African American } \\
\text { race }\end{array}$ & $-15.5(-43.6$ to 12.6$)$ & 0.27 & - & - \\
\hline Hypertension & $-14.6(-42.8$ to 13.6$)$ & 0.30 & - & - \\
\hline Diabetes mellitus & $1.1(-17.7$ to 19.9$)$ & 0.90 & - & - \\
\hline Dyslipidemia & $3.3(-14.2$ to 20.9$)$ & 0.70 & - & - \\
\hline BMI & $0.3(-0.8$ to 1.4$)$ & 0.58 & - & - \\
\hline Smoking & $-1.4(-18.8$ to 16.0$)$ & 0.87 & - & - \\
\hline Baseline GFR & 0.77 (0.59 to 0.95) & $<0.001$ & 0.78 (0.6 to 1.0$)$ & $<0.001$ \\
\hline $\begin{array}{l}\text { Prior radical } \\
\text { nephrectomy }\end{array}$ & $-15.8(-50.6$ to 18.9$)$ & 0.36 & - & - \\
\hline $\begin{array}{l}\text { Prior partial } \\
\text { nephrectomy }\end{array}$ & $2.2(-23.1$ to 27.6$) 0$ & 0.86 & - & - \\
\hline Single kidney & $-21.7(-49.2$ to 5.8$)$ & 0.12 & - & - \\
\hline Prior ablation & $-7.5(-28.9$ to 13.8$)$ & 0.48 & - & - \\
\hline Lesion size & $-7.6(-14.5$ to -0.7$)$ & 0.03 & 0.34 ( -4.1 to 4.8$)$ & 0.88 \\
\hline
\end{tabular}

Table 6-Linear regression for the 6 months after cryoablation time point.

\begin{tabular}{|c|c|c|c|c|}
\hline \multirow[b]{2}{*}{ Variable } & \multicolumn{2}{|l|}{ Univariate analysis } & \multicolumn{2}{|c|}{ Multivariate analysis } \\
\hline & Estimate & $P$-value & Estimate & $P$-value \\
\hline Age & $-0.8(-1.8$ to 0.1$)$ & 0.08 & - & - \\
\hline Male sex & -15.5 (-18.1 to 17.2$)$ & 0.32 & - & - \\
\hline $\begin{array}{l}\text { African American } \\
\text { race }\end{array}$ & $6.3(-33.4$ to 46.1$)$ & 0.73 & - & - \\
\hline Hypertension & $-23.6(-60.0$ to 12.7$)$ & 0.18 & - & - \\
\hline Diabetes mellitus & $21.1(-10.0$ to 52.1$)$ & 0.16 & - & - \\
\hline Dyslipidemia & $10.8(-18.0$ to 39.6$)$ & 0.42 & - & - \\
\hline BMI & $1.2(-0.3$ to 2.7$)$ & 0.1 & - & - \\
\hline Smoking & 20.5 (-7.6 to 48.6$)$ & 0.13 & - & - \\
\hline Baseline GFR & $0.63(0.1$ to 1.2$)$ & 0.03 & $0.41(-0.2$ to 1.02$)$ & 0.16 \\
\hline $\begin{array}{l}\text { Prior radical } \\
\text { nephrectomy }\end{array}$ & $-12.0(-68.6$ to 44.6$)$ & 0.6 & - & - \\
\hline Single kidney & $-10.9(-64.2$ to 42.5$)$ & 0.66 & - & - \\
\hline Prior ablation & $-10.9(-64.2$ to 42.5$)$ & 0.66 & - & - \\
\hline Lesion size & $-12.84(-23.8$ to -1.9$)$ & 0.03 & $-8.6(-20.8$ to 3.6$)$ & 0.15 \\
\hline
\end{tabular}

they presented at baseline: stage G2 (CKD stage 2). At that same time point, the GFR category worsened from G3a to G3b among the patients in the PRI+ group, although the CKD stage remained the same as it had been at baseline: CKD stage 3. In addition, the GFR never dropped below 
$30 \mathrm{~mL} / \mathrm{min} / 1.73 \mathrm{~m}^{2}$ in either group and none of the patients in either group required renal replacement therapy such as dialysis or kidney transplantation.

Regarding the overall trend in our cohort, there were declines in the mean GFR at 1 month and 6 months after cryoablation. The slight improvement in GFR at 12 months in the PRI- group patients was likely due to the presence of healthy nephrons with better regenerative capacity in those patients. Our finding that the mean GFR was significantly lower at all time points among the PRI+ group patients is in keeping with the condition of a history of renal impairment. These findings corroborate those of a study in which patients were followed for 3 months after cryoablation or partial nephrectomy and showed that the post-procedure decline in absolute GFR was significantly greater after cryoablation than after partial nephrectomy, although the rate of CKD stage progression was similar between the two groups, indicating clinical preservation of renal function in both ${ }^{(20)}$.

Our data are complimentary to those in the literature on microwave ablation. For example, Zhou et al. ${ }^{(21)}$ found CT-guided percutaneous microwave ablation to be a safe procedure, post-ablation imaging showing a complete response in $42(95 \%)$ of the 44 tumors ablated and renal function remaining stable at 1 month after ablation. In addition, Urabe et al. ${ }^{(22)}$ found that, among patients undergoing cryoablation, the decline in renal function at 6 months after the procedure was comparable between those with CKD and those without. Those authors found that renal function was significantly impaired in the early post-cryoablation period and did not recover in the 6 months thereafter. In the present study, we assessed renal function for an additional 6 months (total of 12 months of follow-up) and found that, although it was not statistically significant, there was partial recovery of renal function at 12 months among patients without a history of renal injury. A number of studies have investigated the effect that ablation has on renal function in comparison with that of partial nephrectomy, and the results have been mixed ${ }^{(23-27)}$. The rate of renal function decline in our sample is comparable to the approximately $20 \%$ previously reported for patients who have recently undergone partial nephrectomy ${ }^{(4)}$.

Tumor size has been shown to be significantly associated with postoperative renal function, larger tumors increasing the risk of a decline ${ }^{(28)}$. However, it is difficult to determine whether tumor size or baseline GFR is a better individual predictor of postoperative renal function, because they are probably collinear covariates or intermediate variables, i.e., a large lesion may cause the baseline GFR to be lower, which would, in turn, cause the GFR at 6 months to be lower. Our findings resonate with those of Urabe et al. ${ }^{(22)}$, who showed that the percent decline in GFR on postoperative day 1 was the only independent predictor of GFR at 6 months after percutaneous cryoablation of renal tumors. Some of the variables we evaluated as predictors of post-cryoablation renal function are in keeping with those previously evaluated in the literature. Tumor size and location have been described as the most important factors determining whether renal cell carcinomas can be successfully treated ${ }^{(12,29)}$. In addition, the agerelated decline in GFR has been shown to be significantly greater in males than in females, who are thought to be protected by estrogen ${ }^{(30)}$.

Our study has limitations. First, it was a retrospective study involving a small cohort. In addition, the followup period was relatively short. However, the goal of the study was to evaluate trends in and predictors of renal function in the early post-procedure period. Furthermore, there was no external control group of patients undergoing a different treatment for renal tumors. There is a need for additional studies with larger patient samples and longer follow-up periods in order to evaluate longterm outcomes.

\section{CONCLUSION}

In the present study, the trend of post-cryoablation renal function decline was comparable between those with a history of renal impairment and those without. In addition, there was no change in CKD staging after cryoablation, in either group. Although baseline GFR predicts the GFR in the early post-cryoablation period, a review of the factors associated with renal function preservation may improve pre-procedure patient counseling and allow decisions regarding management to be individualized in patients undergoing cryoablation of renal masses.

\section{REFERENCES}

1. Chow WH, Devesa SS, Warren JL, et al. Rising incidence of renal cell cancer in the United States. JAMA. 1999;281:1628-31.

2. Hollingsworth JM, Miller DC, Daignault S, et al. Rising incidence of small renal masses: a need to reassess treatment effect. J Natl Cancer Inst. 2006;98:1331-4.

3. Huang WC, Levey AS, Serio AM, et al. Chronic kidney disease after nephrectomy in patients with renal cortical tumours: a retrospective cohort study. Lancet Oncol. 2006;7:735-40.

4. Mir MC, Ercole C, Takagi T, et al. Decline in renal function after partial nephrectomy: etiology and prevention. J Urol. 2015;193:188998.

5. Tanagho YS, Bhayani SB, Kim EH, et al. Renal cryoablation versus robot-assisted partial nephrectomy: Washington University longterm experience. J Endourol. 2013;27:1477-86.

6. Caputo PA, Ramirez D, Zargar H, et al. Laparoscopic cryoablation for renal cell carcinoma: 100-month oncologic outcomes. J Urol. 2015; 194:892-6.

7. Klatte T, Shariat SF, Remzi M. Systematic review and meta-analysis of perioperative and oncologic outcomes of laparoscopic cryoablation versus laparoscopic partial nephrectomy for the treatment of small renal tumors. J Urol. 2014;191:1209-17.

8. Pandharipande PV, Gervais DA, Mueller PR, et al. Radiofrequency ablation versus nephron-sparing surgery for small unilateral renal cell carcinoma: cost-effectiveness analysis. Radiology. 2008;248:169-78.

9. Kunkle DA, Uzzo RG. Cryoablation or radiofrequency ablation of the small renal mass: a meta-analysis. Cancer. 2008;1 13:2671-80.

10. Psutka SP, Feldman AS, McDougal WS, et al. Long-term oncologic 
outcomes after radiofrequency ablation for $\mathrm{T} 1 \mathrm{renal}$ cell carcinoma. Eur Urol. 2013;63:486-92.

11. Thompson RH, Atwell T, Schmit G, et al. Comparison of partial nephrectomy and percutaneous ablation for cTl renal masses. Eur Urol. 2015;67:252-9.

12. Gervais DA, McGovern FJ, Arellano RS, et al. Radiofrequency ablation of renal cell carcinoma: part 1, Indications, results, and role in patient management over a 6-year period and ablation of 100 tumors. AJR Am J Roentgenol. 2005;185:64-71.

13. Littrup PJ, Ahmed A, Aoun HD, et al. CT-guided percutaneous cryotherapy of renal masses. J Vasc Intervent Radiol. 2007;18:383-92.

14. Silverman SG, Tuncali K, vanSonnenberg E, et al. Renal tumors: MR imaging-guided percutaneous cryotherapy-initial experience in 23 patients. Radiology. 2005;236:716-24.

15. Varkarakis IM, Allaf ME, Inagaki T, et al. Percutaneous radio frequency ablation of renal masses: results at a 2 -year mean follow-up. J Urol. 2005; 174:456-60.

16. Zagoria RJ, Traver MA, Werle DM, et al. Oncologic efficacy of CTguided percutaneous radiofrequency ablation of renal cell carcinomas. AJR Am J Roentgenol. 2007;189:429-36.

17. Atwell TD, Farrell MA, Leibovich BC, et al. Percutaneous renal cryoablation: experience treating 115 tumors. J Urol. 2008;179:213641.

18. Levey AS, Bosch JP, Lewis JB, et al. A more accurate method to estimate glomerular filtration rate from serum creatinine: a new prediction equation. Modification of Diet in Renal Disease Study Group. Ann Intern Med. 1999;130:461-70.

19. [No authors listed]. Summary of recommendation statements. Kidney Int Suppl. 2013;3:5-14.

20. Mason RJ, Atwell TD, Lohse C, et al. Renal functional outcomes in patients undergoing percutaneous cryoablation or partial nephrectomy for a solitary renal mass. BJU Int. 2017;120:544-9.
21. Zhou W, Herwald SE, Uppot RN, et al. Risk assessment of chronic kidney disease following microwave ablation for stage T1 renal cell carcinoma. J Vasc Intervent Radiol. 2018;29:1685-91.

22. Urabe F, Kimura T, Miki J, et al. Estimated glomerular filtration rate on postoperative day 1 is associated with renal functional outcome after percutaneous renal cryoablation for renal tumors. Int J Urol. 2017;24:553-4.

23. Mitchell CR, Atwell TD, Weisbrod AJ, et al. Renal function outcomes in patients treated with partial nephrectomy versus percutaneous ablation for renal tumors in a solitary kidney. J Urol. 2011;186:1786-90.

24. Larcher A, Meskawi M, Valdivieso R, et al. Comparison of renal function detriments after local tumor ablation or partial nephrectomy for renal cell carcinoma. World J Urol. 2016;34:383-9.

25. Faddegon S, Ju T, Olweny EO, et al. A comparison of long term renal functional outcomes following partial nephrectomy and radiofrequency ablation. Can J Urol. 2013;20:6785-9.

26. Raman JD, Raj GV, Lucas SM, et al. Renal functional outcomes for tumours in a solitary kidney managed by ablative or extirpative techniques. BJU Int. 2010;105:496-500.

27. Lucas SM, Stern JM, Adibi M, et al. Renal function outcomes in patients treated for renal masses smaller than $4 \mathrm{~cm}$ by ablative and extirpative techniques. J Urol. 2008;179:75-80.

28. Mukkamala A, He C, Weizer AZ, et al. Long-term renal functional outcomes of minimally invasive partial nephrectomy for renal cell carcinoma. Urol Oncol. 2014;32:1247-51.

29. Gervais DA, Arellano RS, McGovern FJ, et al. Radiofrequency ablation of renal cell carcinoma: part 2, Lessons learned with ablation of 100 tumors. AJR Am J Roentgenol. 2005;185:72-80.

30. Berg UB. Differences in decline in GFR with age between males and females. Reference data on clearances of inulin and PAH in potential kidney donors. Nephrol Dial Transplant. 2006;2 1:2577-82. 